\title{
Cultivation and economic prospects of Betel Nut (Areca catechu Linn.) and Coconut (Cocos nucifera Linn.) in rural economy: A case study from southeastern region of Bangladesh
}

\author{
Nandi Rajasree*, Hossain Akhter, Anwar Nurul \\ Institute of Forestry and Environmental Sciences, University of Chittagong, Rajasree Nandi, Assistant \\ Professor, Institute of Forestry and Environmental Sciences, University of Chittagong, 4331 \\ Chittagong, Bangladesh
}

Received: 18 December 2017

Accepted: 26 September 2018

Published online: 30 December 2019

\begin{abstract}
Betel Nut and Coconut are two important crops in the homesteads and farmlands of SouthEastern region of Bangladesh. An exploratory survey to assess the cultivation, contribution and importance of palm husbandry in rural economy was conducted at Ramu upazila under Cox's Bazar District, Bangladesh. A total of 120 households' heads were interviewed who were selected following stratified random selection method. The findings revealed that betel nut contributes $19.06 \%$ (78345 TK) of total annual household income whereas coconut contributes $6.07 \%$ (25017 TK). Orchard, pond bank, homestead and road sides were the four cultivation sites of both palms. Orchards were at top of farmer's preference for cultivating betel nuts while homesteads are of greater preference to farm holders for coconut trees. Annual production of betel nut was highest ( 547 betel nuts per tree) at their 11-20 years age range. Annual production per coconut tree was maximum (58 coconuts) at 21-30 years age class. The availability of palm trees of different age classes reflects a sustainable production system of betel nut and coconuts in the study area. Palm husbandry could be a promising sector of rural economy in Bangladesh if the marketing system is well developed reducing involvement of middlemen in the business.
\end{abstract}

Keywords: distribution pattern, sustainable production, palm husbandry, household income, Palm Action Plan

\section{Introduction}

Rural home gardens having enormous contribution to the national economy of Bangladesh is widely recognized (Roy et al. 2013). The home gardens are traditionally accompanied with diverse plant species to provide food, fodder, fuel-wood, medicinal herbs, building materials as well as income and employment to the rural people (Randhawa 1980; Rani et al. 2003; Wiersum 2006; Glowacki 2012). Coconut (Cocos nucifera L.) and betel nut (Areca catechu L.) are the two most common palms, generally, cultivated with many other plant species for effective use of smallholders' farms and homesteads. In the tropics, these species support livelihoods for millions of people (Randhawa 1980;

\footnotetext{
${ }^{*}$ Corresponding author: Nandi Rajasree
} e-mail: rajasree@cu.ac.bd 
Nath et al. 2011). Other than the homesteads, these palms are widely planted in the pond banks, canal banks, highlands and orchards. Both the palms are compatible with many agricultural species hence also used as intercrop (Chan and Elevitch 2006; Staples and Bevacqua 2006).

Coconut (Cocos nucifera), a native to coastal areas (the littoral zone) of Southeast Asia and Melanesia; was introduced or dispersed pantropically. More than 11 million farmers, mostly smallholders with low income, grow the palm in over 90 countries (Chan and Elevitch 2006; Rethinam and Singh 2007). Coconut is one of the staple foods in Indonesia and Malaysia as it is cooked with taro, banana, fishes etc. In Bangladesh, coconut is cultivated over 2,287 hectares of land which produces about 372,006 metric tons of coconut per year. Bangladesh earned 351,000 BDT from exporting coconut in 2011-2012 fiscal years (BBS 2012). It was also reported from BBS (2012) that a total of 103,309 people was involved in growing fruits including coconut. The palm is prominently valued due to it's fruit, beverage, leaf, fiber and stem which contribute as food, thatching material, timber, fuelwood, weaving mat, wind break, raw material for oil extraction, canoe making etc. (Chan and Elevitch 200; Mitchell and Ahmad 2006; Calzada et al. 2007; Al-Adhroey 2011). Rural areas of tropics and subtropics face multiple challenges; hence the suggested solutions and development activities should be properly customized (Mechik et. al. 2017). Cultivation of coconut was emphasized by the scientific communities for it's contribution in nutrition, increasing farmers' income, providing employment to the rural women, saving foreign exchange and coastline protection (Molla et al. 2004; Lamanda et al. 2006). The economic shares made the plant an important homestead and plantation crops of Bangladesh with multipurpose uses.

Betel nut, though originated in Philippine, is widely grown in all over Bangladesh along with many countries of South and South-East Asia and East Africa. The plant, mainly cultivated for nut or seed production, which is an essential part of betel pepper has important medicinal values as well (Nath and Karmakar 2001; Staples and Bevacqua 2006). Researchers reported important and useful chemical ingredients present in the areca nut which made it a basic element of betel quid and enhanced it's commercialization (Arjungi 1976; Gupta and Warnakulasuriya 2002). Moreover, the plant is commonly used for timber, fuelwood, beautification, weaving and wrapping along with many other purposes (Staples and Bevacqua 2006). World production of areca nut is increasing where Bangladesh is a significant contributor to the agricultural base of areca-nut production because of it's commercialization, but its production and use by the Bangladeshi population is not well documented (FAO 2003).

In Bangladesh about 72.4 million people live in the rural areas and depend mainly on agriculture and tree-based economic activities for their subsistence (BBS 2012). Since rural household incomes depend mainly on agriculture so landholdings, farm area and cultivation techniques greatly determine the household economy. Several productive palm-crop associations with satisfactory production were also identified in Bangladesh by Dalibard (2007). Dowson (1982) mentioned that a significant economic return is possible from coconut and areca nut if cultivated systematically. It is evident that researchers investigated and reported different aspects of betel nut and coconut (Lima et al. 2015; Iqbaldin et al. 2013; Pin et al. 2010; Novarianto and Warokka 2005; Etherington 2005; Samosir et al. 2005). Though both coconut and areca nut provides good economic return but very little attention is paid for exploring their economic potentiality in the homesteads and marginal farms of Bangladesh, developing systematic cultivation techniques to yield maximum production. There is also dearth of research about the status and distribution of coconut and betel nut in the traditional rural farms. Site specific production and contributions of these palms to rural economy was not explored as well. It is worth mentioning that agriculture sector of Bangladesh is contributing around 17\% of it's GDP and employed above 45\% labor force of the country (BBS 2012). In this view, the Peoples Republic of Bangladesh set priorities for agricultural sector to ensure food security, poverty alleviation and enhanced employment opportunities. Ramu is one of the famous upazilas under Cox's Bazar district of Bangladesh for 
R. Nandi et al.

extended cultivation of betel nut and coconut at farmer level. There exists the information gap since the extent and pattern of cultivation as well as it's contribution to rural economy is not explored at all.

In this connection, the present study was conducted to fill the research gap through highlighting the contribution of coconut and betel nut to rural economy in Ramu upazila under Cox's Bazar district of south-eastern Bangladesh where coconut and betel nut are cultivated widely in the rural households. The study aimed to explore the distribution, production, economic contribution of palm husbandry to rural economy of Ramu upazila in Cox's Bazar District of Bangladesh.

\section{Methods of the study}

\section{Study area}

The study was conducted at Ramu upazila (sub-district; administrative entity) under Cox's Bazar district, south-eastern region of Bangladesh (Fig. 1). Ramu upazila with an area of $391.7 \mathrm{~km}^{2}$ is bounded by Bay of Bengal on the west and hilly terrain (small to medium hills) of Chittagong Hill Tracts and Cox's Bazar on other three sides (Banglapedia 2014). The region is famous for betel nut and coconut production. Land use data revealed that the total cultivable land of Ramu is 12,750 hectares of which $65 \%$ land is under irrigation. Main crops are paddy, potato, chili, onion, garlic, betel leaf. Previously sweet potato and sugarcane were major export crops but now-a-days betel nut, coconut and betel leaf are grown abundantly and exported to other regions instead (Banglapedia 2014).

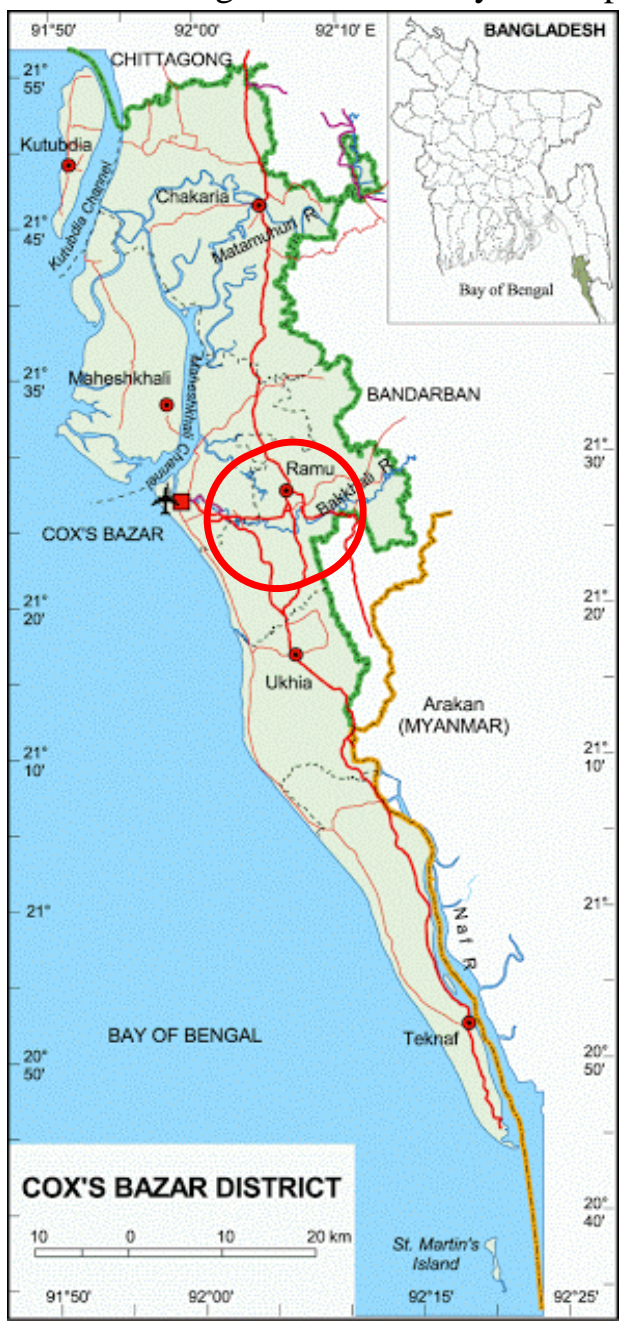

Fig. 9. Map of Cox's Bazar district showing the study area (marked by red circle). 


\section{Study area selection}

Palm tree species are one of the major plantation trees for their fruits in the south-eastern region of Bangladesh. Ramu upazlia of Cox' Bazar, one of the five districts from south-eastern region of Bangladesh, was selected for the study. Following stratified random sampling method 7 union councils were selected among the 11 union councils of Ramu upazila. From each of 7 union councils, 4 villages were selected randomly for household survey. Again, 40 households were randomly selected as sampling unit for interview from each of the 4 villages.

\section{Data collection}

Household heads were interviewed with the help of a pre-field-tested semi-structured questionnaire. The households were grouped into three categories based on their landholding i.e. (i) small (0 to $1.0 \mathrm{ha}$ ), (ii) medium (1.10 to 2.0ha) and (iii) large (>2.0 ha). We chose the households as the sampling unit to collect data taking into consideration the fact that the household head is the decisionmaker and knows all the facts related to coconut and betel nut husbandry in his farms. Thus, data on occupational patter, distribution of coconut and betel nut in the households, income received from cultivation of these nuts were collected from a total of 112 households of Ramu upazila. While exploring the annual income, the households were requested to provide the actual amount in Bangladeshi Taka (BDT: national currency measurement; US\$ $1=$ BDT 78, during the study period, i.e., in 2015).

\section{Data analysis}

The structural characteristics of the coconut and betel nut stands in the households were assessed in terms of distribution and density (Alam and Sarker 2011). The household heads were asked the present value of coconut and betel nut and amount of those palms consumed by them annually. We considered the total production received by the household in last one year from the interview date to calculate the mean annual income, cost and revenue gained. Mean annual value of products and revenue from sale of coconut and betel nut (BDT/household/year) were calculated.

Spearman correlation coefficients were derived to check association between the mean annual income, cost and revenue received, and farm size. Kruskal Wallis test was done to find significant difference among income, cost and revenue received by different farm categories.

\section{Results and discussion}

\section{Occupational pattern of betel nut and coconut farmers}

Occupation is an important characteristic of an individual, which may be a determinant of his opportunity. The result of the study showed that people of Ramu upazila are involved in diverse economic activities for sustenance among which maximum (67\%) respondents were engaged in agriculture followed by business (17\%), service (9\%), day labor (5\%) and other occupations (3\%). It indicated that among the diversified occupations agro-farm based activities is the major source of income. This result corresponds to the reports of Banglapedia (2014) which estimated agriculture as the major economic activity (47.46\% depend on agriculture in that region) followed by agricultural laborer (14.20\%), commerce $(9.83 \%)$, service $(7.74 \%)$ and wage laborer $(4.01 \%)$ etc. Percentage of people doing business was higher in the present study than the reports of Banglapedia (2014) and BBS (2012) which indicated peoples' trend of shifting towards non-farm based economic activities. 


\section{Coconut and betel nut cultivation in three household categories}

The result of the study revealed that number of coconut and betel nut trees varied with the household category. Farmers of large household category possessed 346 palm (coconut and betel nut) individuals (45\% of 783), which was highest among those of the three different household categories. On the other hand, the small household category possessed only 167 individuals (21\% of 783), which was lowest among the three categories (Fig. 2). The result indicated that all households are involved in palm husbandry but extant increase with size of land holdings.

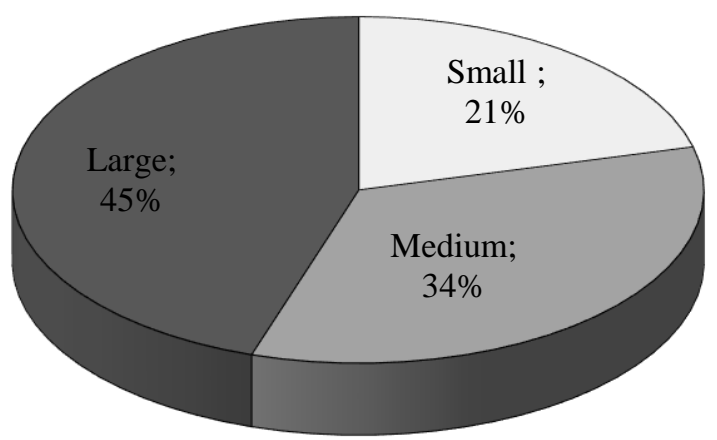

Fig. 2 Palms owned by different household categories.

\section{Distribution of betel nut and coconut at different lands in and around households}

Residents of the study area cultivate betel nut and coconut in homestead, orchard, pond bank and road sides adjacent to their house. Distribution of betel nut and coconut individuals varied with the location of cultivation and household size. The results indicated that individual of betel nut was maximum (70\% in average) in the orchards of all household categories followed by homesteads (14\%), pond bank (8\%) and road sides (8\%) (Fig. 3a). Betel nut distribution among the households indicated that choice of land (homesteads, orchards, pond banks and roadsides) for its cultivation is almost similar in all household categories.

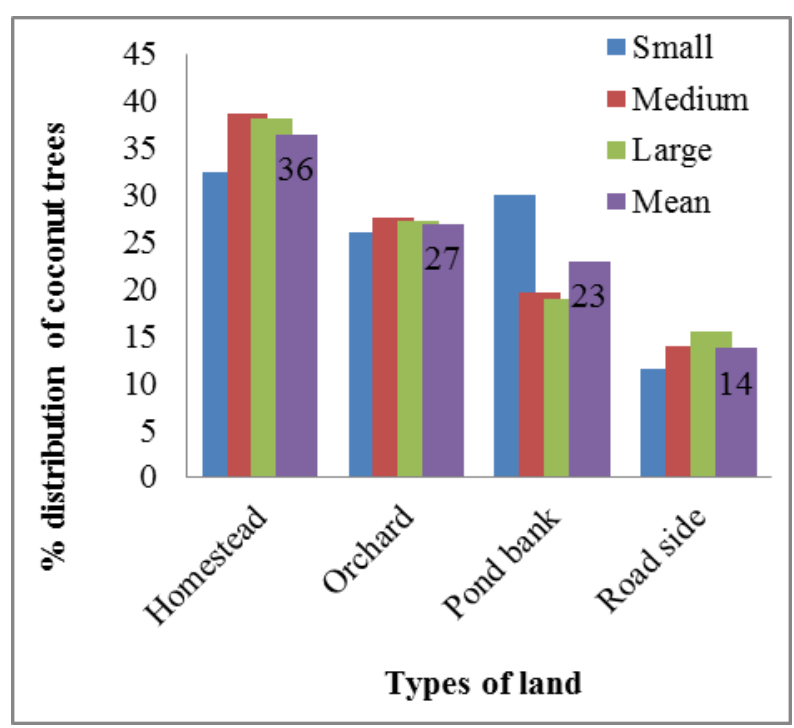

Fig. 3(a) Distribution of betel nut trees into different household categories of Ramu, Cox's Bazar. 


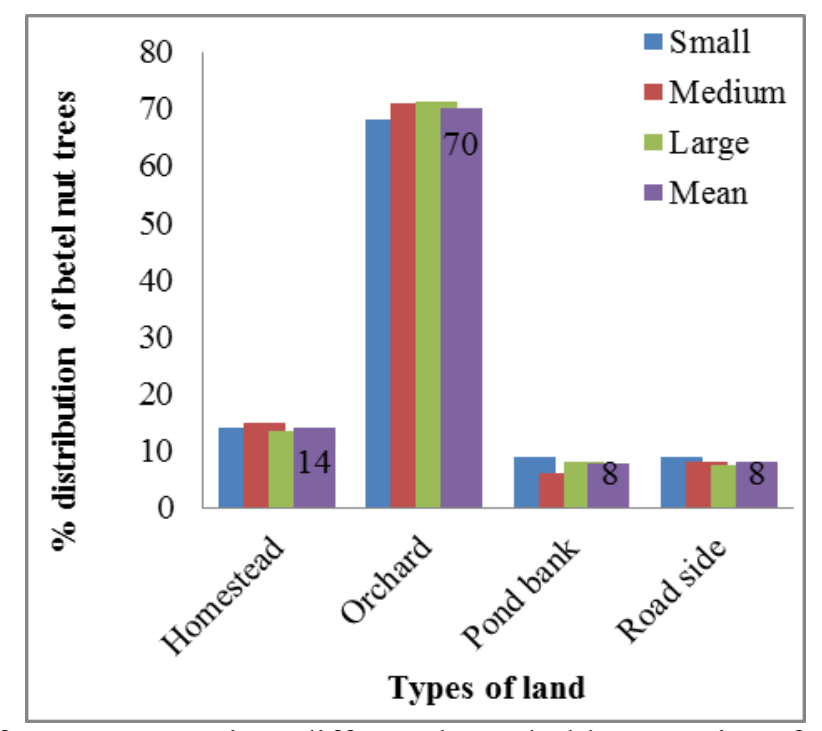

Fig. 3(b) Distribution of coconut trees into different household categories of Ramu, Cox's Bazar.

The results also indicated that, maximum number of coconut plants occurred in the homesteads (36\%) followed by orchard (27\%), pond bank (23\%) and road sides (14\%). Occurrence of coconut individuals, in most of the cases, is higher in medium households followed by large and small households in homestead, orchard, pond bank and road side (Fig. 3b).

\section{Age class distribution of betel nut and coconut}

Presence of palm of different age classes is very much important for sustainable production of betel nut and coconut in the whole study area. Individuals of betel nut and coconut palms were classified into five age classes i.e. $\leq 10$ years, $11-20$ years, 21 - 30 years, $31-40$ years and $>40$ years. The survey indicated that, number of betel nut trees in all the age classes and farm categories are almost comparable. It indicates a sustainable and continuous production of betel nut in the homesteads of Ramu. Moreover, in large homesteads higher percentage of betel nut trees were found which indicate a positive relation with the farm size.

Distribution of coconut into different age class and households indicated that small households are planting coconut as number of coconut trees in age class $\leq 10$ years was higher than medium and large household categories (Fig. 4). Coconut trees of $\geq 40$ years age have fewer occurrences in small households it may be because of little space available for its cultivation. But, medium household showed higher occurrences of coconut trees in 11-20 and 31-40 years age class. There is no regular pattern or trend of occurrence of coconut plants in different households. However, it indicated medium households have comparatively higher preference to coconut cultivation than others.

\section{Production of betel nut and coconut in different age ranges}

The study revealed that production capacity of betel nut varies with age classes. Betel nut tree starts their production at the age of 6-8 years which reduces after 30 years old. The annual production of betel nuts per tree showed a gradual increase with age which reached at it's peak in 11-20 years old and starts a gradual falling after that (Tab. 1). Production capacity per tree was highest ( $547 \pm 23$ betel nuts) at the 11-20 years age range and least ( $133 \pm 7$ betel nuts) at $>40$ years age range.

Production of coconut, starting at the age of 6-8 years, varies with age of coconut trees. The survey indicated that the annual yield of mature coconut reaches to its maximum at the age range of 2130 years ( $58 \pm 1.18$ coconuts per tree) which starts reducing after that (Tab. 1$)$. According to the farmers, at the early stages of production the coconuts were larger in size though quantity produced per tree (28 
R. Nandi et al.

coconuts) is less than immediately higher age range. Annual production of coconut per tree was least $(27 \pm 1.44$ nos.) at ages of $>40$ years. It is evident that production capacity is gradually decreasing with increasing age after 30 years old.

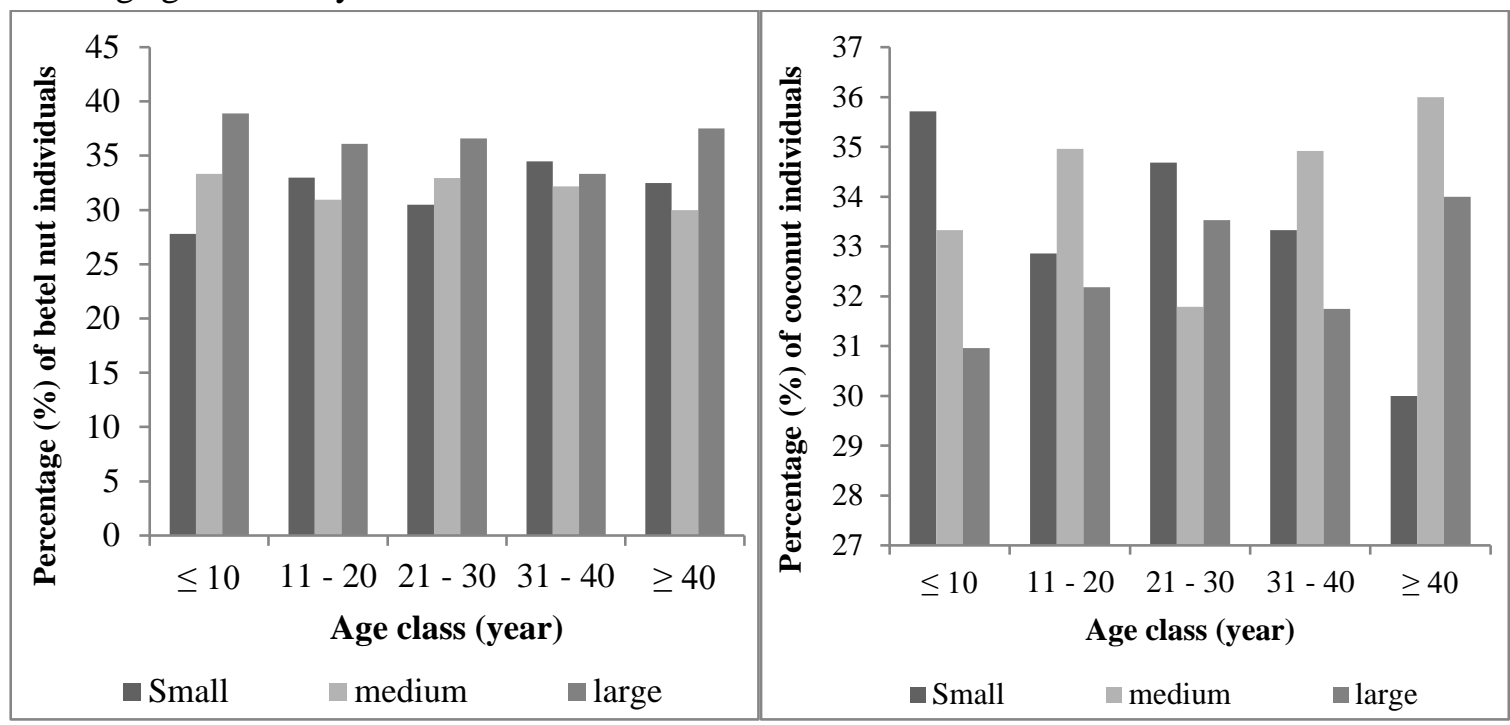

Fig. 4. Age class distribution of betel nut (left) and coconut (right) trees over the study area.

Tab. 1. Production capacity of betel nut and coconut per individual tree by age classes.

\begin{tabular}{|c|c|c|c|c|c|c|}
\hline \multirow[t]{2}{*}{$\begin{array}{l}\text { Household } \\
\text { category }\end{array}$} & \multicolumn{5}{|c|}{$\begin{array}{c}\text { Annual production of betel nut (nos.) per individual tree at } \\
\text { different age classes }\end{array}$} & \multirow{2}{*}{$\begin{array}{l}\text { Average } \\
\text { production } \\
\text { (nos.) }\end{array}$} \\
\hline & $\begin{array}{c}<10 \\
\text { (year) }\end{array}$ & $\begin{array}{l}11-20 \\
\text { (year) }\end{array}$ & $\begin{array}{l}21-30 \\
\text { (year) }\end{array}$ & $\begin{array}{l}31-40 \\
\text { (year) }\end{array}$ & $>40$ (year) & \\
\hline Betel nut & $177 \pm 11$ & $547 \pm 23$ & $323 \pm 11$ & $290 \pm 4$ & $133 \pm 7$ & $221 \pm 10$ \\
\hline Coconut & $28 \pm 0.94$ & $48 \pm 0.98$ & $58 \pm 1.18$ & $42 \pm 0.94$ & $27 \pm 1.44$ & $30 \pm 0.54$ \\
\hline
\end{tabular}

\section{Yield and net income from betel nut cultivation}

The price of betel nut depends on the size and different circumstances such as natural calamities, demand, supply and economic condition at home and abroad. The price also varies by districts within Bangladesh based on production and supply. From the survey, it was found that average price of each betel nut is BDT 1.50. The study indicated that annual harvested betel nut per household was 56,008 $\pm 1,164$ nos. Annual net income from betel nut was BDT 78,345 per household which ranged from a minimum of BDT 42,305 in small household to a maximum BDT 113,360 in large households (Tab. 2). The Kruskal-Wallis and the pairwise Mann-Whitney-Wilcox test indicated that the sale amount, management cost and net income per household differs significantly at $\mathrm{p}<0.05$ in small to large farm categories.

Tab. 2. Yield and annual income from betel nut cultivation at Ramu, Cox'sBazar.

\begin{tabular}{|l|l|l|l|l|}
\hline $\begin{array}{l}\text { Household } \\
\text { category }\end{array}$ & $\begin{array}{l}\text { Nut harvested } \\
\text { per year per } \\
\text { household (No.) }\end{array}$ & $\begin{array}{l}\text { *Total sale } \\
\text { (BDT) }\end{array}$ & $\begin{array}{l}\text { Management } \\
\text { cost (BDT) }\end{array}$ & $\begin{array}{l}\text { Net income of } \\
\text { each household } \\
\text { (BDT) }\end{array}$ \\
\hline Small & $30,870 \pm 430^{\mathrm{b}}$ & $46,305 \pm 330^{\mathrm{a}}$ & $4,000 \pm 144^{\mathrm{a}}$ & $42,305 \pm 295^{\mathrm{a}}$ \\
\hline Medium & $56,914 \pm 461^{\mathrm{b}}$ & $85,370.4 \pm 323^{\mathrm{b}}$ & $6,000 \pm 98^{\mathrm{b}}$ & $79,370 \pm 349^{\mathrm{b}}$ \\
\hline Large & $80,240 \pm 642^{\mathrm{b}}$ & $120,360 \pm 473^{\mathrm{c}}$ & $7,000 \pm 198^{\mathrm{c}}$ & $113,360 \pm 348^{\mathrm{c}}$ \\
\hline Mean & $56,008 \pm 1,164^{\mathrm{b}}$ & $84,011 \pm 2,698^{\mathrm{b}}$ & $5,666 \pm 138^{\mathrm{b}}$ & $78,345 \pm 2,562^{\mathrm{b}}$ \\
\hline
\end{tabular}

*Figures in the same column having the same letter or no letter do not differ significantly at $p<0.05$ based on Kruskal-Walis and the pairwise Mann-Whitney-Wilcox test 


\section{Yield and net income from Coconut}

The study revealed that yield of coconut varies considerably with tree age and site quality. The principal marketable coconut products are green coconut and mature coconut. Green coconut water is taken as beverage while mature coconut is used with different food items and for oil extraction. Price of green coconut and matured is almost same varies with seasons and occasion of religious as well as social festivals. The survey indicated that, whole selling price of each coconut is BDT 20 in average (Tab. 3). Annual harvest of coconut per household was $1,451 \pm 264$ nos. The net income received from coconut by each household was BDT 25,016 \pm 726 in average. The number of coconut harvested and net income from that was higher in the larger household category. The Kruskal-Wallis and pairwise MannWhitney-Wilcox test indicated that the increase of production (value), management cost and net income from coconut with the household category was significantly different at $\mathrm{p}<0.5$.

Tab. 3. Yield and annual income from Coconut cultivation at Ramu, Cox's Bazar.

\begin{tabular}{|l|l|l|l|l|}
\hline $\begin{array}{l}\text { Househol } \\
\text { d category }\end{array}$ & $\begin{array}{l}\text { Coconut harvested } \\
\text { per year per HH (No.) }\end{array}$ & $\begin{array}{l}\text { Annual sale value } \\
\text { per year (BDT) }\end{array}$ & $\begin{array}{l}\text { Annual } \\
\text { management cost } \\
(\text { BDT) }\end{array}$ & $\begin{array}{l}\text { Net income } \\
\text { per HH (BDT) }\end{array}$ \\
\hline Small & $857 \pm 246^{\mathrm{a}}$ & $17,138 \pm 218^{\mathrm{a}}$ & $2,500 \pm 57^{\mathrm{a}}$ & $14,638 \pm 191^{\mathrm{a}}$ \\
\hline Medium & $1,523 \pm 347^{\mathrm{b}}$ & $30,459 \pm 292^{\mathrm{b}}$ & $4,000 \pm 137^{\mathrm{b}}$ & $26,459 \pm 230^{\mathrm{b}}$ \\
\hline Large & $1,973 \pm 352^{\mathrm{c}}$ & $39,454 \pm 245^{\mathrm{c}}$ & $5,500 \pm 113^{\mathrm{c}}$ & $33,954 \pm 230^{\mathrm{c}}$ \\
\hline Mean & $1,451 \pm 264^{\mathrm{b}}$ & $29,016 \pm 835^{\mathrm{b}}$ & $4,000 \pm 125^{\mathrm{b}}$ & $25016 \pm 726^{\mathrm{b}}$ \\
\hline
\end{tabular}

\section{Contribution of palm tree species in total annual income}

Palm husbandry is one of the important means of livelihood in rural Bangladesh. It plays an active role in the contribution to rural economy, to the cultural heritage of the countrymen as well (FAO 2007). A significant economic return is possible from the cultivation of palm (Dowson 1982; Naik 1963). Our study revealed that the total average annual income for large household category was BDT $450,000 \pm 16,532$ followed by medium household category (BDT 400,000 $\pm 12,244$ ) and small household category (BDT 360,000 $\pm 9,262$ ). Both coconut and betel nut palms contribute maximum (BDT $147,313 \pm 15,430$ ) income to large households followed by medium (BDT $105,829 \pm 12,745$ ) and small (BDT 56,943 $\pm 5,320$ ) households annually (Tab. 4). By selling of palm products the farmer can uplift their socio-economic condition.

Tab. 4. Annual economic contribution of betel nut and coconut on livelihood of the study area

\begin{tabular}{|l|l|l|l|l|l|l|}
\hline $\begin{array}{l}\text { Household } \\
\text { Category }\end{array}$ & $\begin{array}{l}\text { Family income } \\
\text { (BDT) }\end{array}$ & \multicolumn{2}{|c|}{ Net income (BDT) } & \multicolumn{2}{|l|}{$\begin{array}{l}\text { Total } \\
\text { from income } \\
\text { palms }\end{array}$} & \multicolumn{2}{|c|}{$\begin{array}{l}\text { Contribution in family } \\
\text { income (\%) }\end{array}$} \\
\cline { 3 - 7 } & & Betel nut & Coconut & BDT) & Betel nut & Coconut \\
\hline Small & $360,000 \pm 9,262$ & $42,305 \pm 295$ & $14,638 \pm 191$ & $56,943 \pm 5,320$ & $11.75 \pm 1.7$ & $4.07 \pm 3.3$ \\
\hline Medium & $400,000 \pm 12,244$ & $79,370 \pm 349$ & $26,459 \pm 230$ & $105,829 \pm 12,745$ & $19.84 \pm 2.9$ & $6.61 \pm 3.3$ \\
\hline Large & $450,000 \pm 16,532$ & $113,360 \pm 348$ & $33,953 \pm 230$ & $147,313 \pm 15,430$ & $25.61 \pm 4.2$ & $7.55 \pm 3.3$ \\
\hline Mean & $436,666 \pm 21,256$ & $\begin{array}{l}78,345 \\
2,562\end{array}$ & $25,016 \pm 726$ & $103,362 \pm 21,324$ & $19.06 \pm 3.3$ & $6.07 \pm 0.84$ \\
\hline
\end{tabular}

Palm trees contribute $32 \%$ of total annual income to large household category followed by medium household category (26\%) and small household category (15\%) (Fig. 5). Finally, in the study area, palm tree contributes $25 \%$ of total annual income of the households (Fig. 6). 


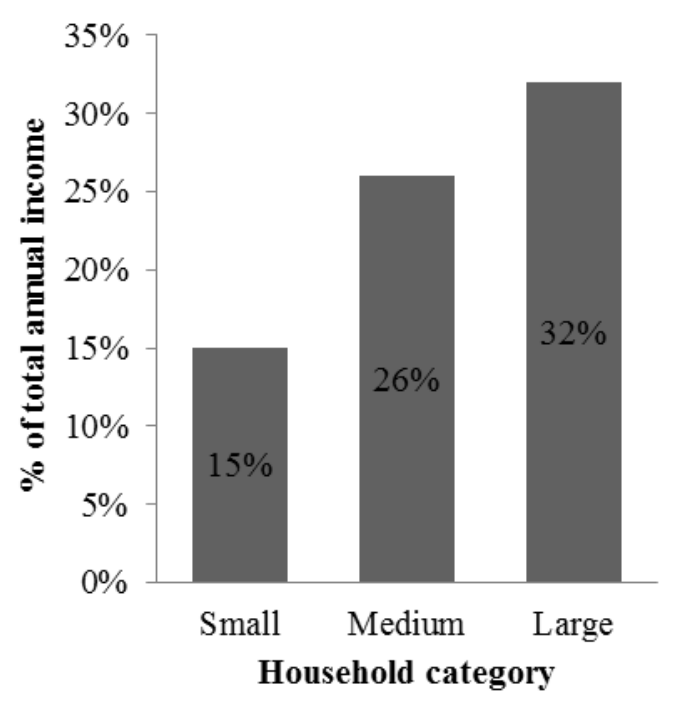

Fig. 5. Household income from palm trees.

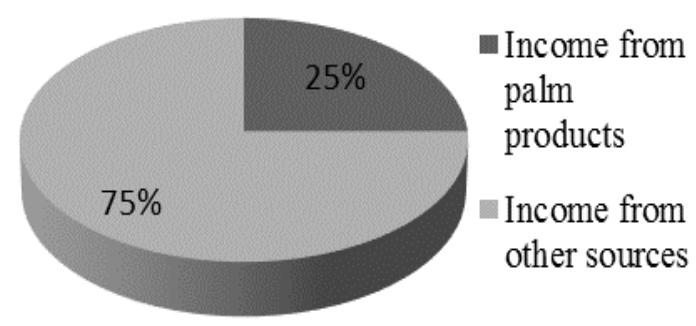

Fig. 6. Annual income sources of household.

\section{Marketing system of the products}

According to the households' opinion, majority of the palm products are sold to the local markets through middlemen. In some cases, they directly sold it to the local market. Some problems were observed in the marketing system of harvested betel nut and coconut. The local farmer doesn't get the proper price of their product due to improper marketing system. Sometimes the middlemen get the maximum benefit from the farmer products. This is due to lack of marketing knowledge and available market knowledge and available market information as well as marketing facilities. The price variation might be higher than the stated price, as the middlemen generally do not state the real price. The similar barriers of getting better price due to the presence of middlemen in the marketing channel was also reported by Bakht (1984), Warner (1995), Halim et al. (2008) and Chowdhury et al. (2008).

\section{Conclusion}

Betel nut and coconut palm cultivation in the homestead have a very strong influence on the rural economy. At the same time, betel nut and coconut meet the demands of nut and provide a significant support to their livelihood. A number of rural people get employment opportunities in different activities related to betel nut and coconut palm such as plantation, management, harvesting and marketing of products. Most of the time farmers are deprived from actual value of betel nut and coconut. Availability of planting materials, easy establishment and low investment in the management of trees, long fruit bearing period, huge demand of betel nut and coconut are some of the opportunities 
for farmers to grow betel nut and coconut trees and generate sustained household incomes. The farmers follow traditional production, less productive technologies in the tree management and harvesting system. The production of betel nut and coconut are under threat of declining due to interferences of diseases, natural calamities and climate change. Palm based production system serves as one of the most important means of improving the economic, social and ecological standard in the rural area of Bangladesh. The IUCN palm specialist group has already declared the Palm Action Plan (PAP) with a view to conserve the palms and to explore their utilization worldwide (Chowdhury et al. 2008). It might be the time for the policy makers in Bangladesh to pay their attention to assess the potentials of palm and to extend cooperation to support related research activities for the purpose of adding a feather of success in the crown of the Palm Action Plan.

\section{References}

Al-adhroey AH, Nor ZM, Al-Mekhlafi HM, Amran AA, Mahmudr (2011) Evaluation of the use of Cocos nucifera as antimalarial remedy in Malaysian folk medicine. Journal of Ethnopharmacology 134: 988-991.

Alam M, Sarker SK (2011) Homestead agroforestry in Bangladesh: dynamics of stand structure and biodiversity. Journal of Sustainable Forestry 30:584-599.

Arjungi KN (1976) Areca nut: A review. Arzneim.-Forsch. (Drug Res) 26: 951-957.

Bakht Z (1984) Entrepreneurship in Bangladesh rural industries. Bangladesh Development Studies XII: 25-58.

Banglapedia (2014) National encyclopedia of Bangladesh. Asiatic Society of Bangladesh, Dhaka.

BBS (2012) Statistical Year Book of Bangladesh. Online: www.bbs.gov.bd/WebTestApplication/userfiles/Image/SubjectMatterDataIndex/YB-2012.pdf websites: BBS. Available from: www.bbs.gov.bd [11 September 2017].

Calzada F, Yepez-Mulia L, Tapia-Contreras A (2007). Effect of Mexican medicinal plant used to treat trichomoniasis on Trichomonas vaginalis trophozoites. Journal of Ethnopharmacolpgy 113: 248251.

Chan E, Elevitch CR (2006) Species Profiles for Pacific Island Agroforestry, Cocos nucifera (Coconut). Websites: traditionaltree. Available from: www.traditionaltree.org_[11 September 2017].

Chowdhury MSH, Halim MA, Muhammed N, Haque F, Koike, M (2008) Traditional utilization of wild date palm (Phoenix sylvestris) in rural Bangladesh: an approach to sustainable biodiversity management. Journal of Forestry Research 19: 245-251.

Dalibard C (2007) The potential of tapping palm trees for animal production. Websites: FAO. Available from: http://www.fao.org/AG/AGAINFO/resources/documents/frg/conf96htm/dalibard.htm [25 April 2017].

Dowson VHW (1982) Date production and protection. FAO Plant Production and Protection Paper No. 35, Food and Agriculture Organization, Rome, Italy.

Lima EBC, Sousa CNS, Meneses LN, Ximenes NC, Santos Junior MA, Vasconcelos GS, Lima NBC, Patrocinio MCA, Macedo D, Vasconcelos SMM (2015) Cocos nucifera L.: A phytochemical and pharmacological review. Brazilian Journal of Medicine and Biological Research 48:953-964.

Etherington D (2005) Bringing hope to remote island communities with virgin coconut oil production. Pp 57-64 in Adkins SW, Foale M \& Samosir YMS (eds) Coconut revival-new possibilities for the 'tree of life'. Proceedings of the International Coconut Forum held in Cairns. 22-24 November 2005, Australia.

FAO (FOOD AND AGRICULTURE ORGANIZATION) (2007) Date palm sap. Available at http://www.fao.org/ DOCREP/006/Y4360I/y4360e03.htm. Accessed 18 October 2017..

FAO (2003) FAO Statistical Databases: Agriculture. Websites: FAO, Available from: http://apps.fao.org/page/ collections?subset=agriculture, under Crops Primary [11 September 2017].

Glowacki R, Barbu MC, Wijck J VAN \& Chowana P (2012) The use of coconut husk in high pressure laminate production. Journal of Tropical Forest Science 24: 27-36.

Gupta PC, Warnakulasuriya, S (2002) Global epidemiology of areca nut usage. Addiction Biology 7: 77-83. 
R. Nandi et al.

Halim MA, Chowdhury MSH, Muhamed N, Rahman M, Koike, M (2008) Sap production from khejur palm (phoenix sylvestris Roxb) husbandry: A substantial means of seasonal livelihood in rural Bangladesh. Forests Trees and Livelihoods 18: 305-318.

Iqbaldin MMM, Khudzir I, Azlan MIM, Zaidi AG, Surani B, Zubri Z (2013) Properties of Coconut Shell Activated Carbon, Journal of Tropical Forest Science 25: 497-503.

Lamanda N, Malezieux E, Martin P (2006) Structure and dynamics of coconut-based agroforestry systems in Melanesia: A case study from the Vanuatu archipelago. Pp 105-121 in Kumar BM \& Nair PKR (eds). Tropical Homegardens: A time-tested example of sustainable agroforestry. Springer, Dordrecht.

Mechik E, Vonhauff M, De Moura LHL, Held H (2017) Analysis of the changes in economic activities of Brazilian forest communities after methodical support and provision of pre-financing capital. Journal of Tropical Forest Science 29: 227-37. http://www.jstor.org/stable/44160940.

Mitchell SA, Ahmad MH (2006) A review of medicinal plant research at the University of the West Indies, Jamaica, 1948-2001. West Indian Medicinal Journal 55: 243-269.

Molla MMH, Bhuiyan MSA, Khananam MD, Batugal P( 2004) In vitro Coconut (Cocos nucifera L.) embryo culture in Bangladesh. Biotechnology 3: 98-101.

Naik KC (1963) South Indian fruit and their culture ( $\left.1^{\text {stedn}}\right)$. Varadachary \& Co., Madras, India, pp. 313.

Nath TK, Karmakar NC (2001) Traditional farming system of Supari (Areca catechu L.) in rural Bangladesh. Palms 45: 109-113.

Nath TK, Inoue M, Pradhan FE, Kabir, MA (2011) Indigenous Practices and Socioeconomics of Areca catechu L. and Piper betel L. based Innovative Agroforestry in Northern Rural Bangladesh. Forests, Trees and Livelihoods 20: 175-190.

Novarianto H, Warokka J (2005) Past, present and future coconut research in Indonesia. Pp 23-27. in Adkins SW, Foale M \& Samosir YMS (eds) Coconut revival-new possibilities for the 'tree of life'. Proceedings of the International Coconut Forum held in Cairns. 22-24 November 2005, Australia.

Pin KY, Chuah AL, Rashih AA, Mazural M, Fadzureena J, Vimala S, Rasadah MA (2010) Antioxidant and Anti-inflammatory activities of extracts of betel leaves (Piper betel) from solvents with different polarities. Journal of Tropical Forest Science 22: 448-455.

Randhawa MS (1980) A history of agriculture in India. Volume 1. ICAR, New Delhi.

Rani SS, Murthy KSR, Goud PSP, Pullaiah T (2003) Tree Wealth in The Life and Economy of The Tribespeople of Andhra Pradesh, India. Journal of Tropical Forest Science 15: 259-278.

Rethinam P, Singh SP( 2007) Current status of the coconut beetle outbreaks in the Asia-Pacific region. Pp 1-23 in Appanah et al. (eds) Developing an Asia-Pacific Strategy for Forest Invasive Species: The Coconut Beetle Problem-Bridging Agriculture and Forestry. RAP publication, Thailand.

Roy B, Rahman M, Fardusi J (2013) Status, Diversity, and Traditional Uses of Homestead Gardens in Northern Bangladesh: A Means of Sustainable Biodiversity. ISRN Biodiversity Volume 2013, Article ID 124103, 11 pages.

Samosir UMS, Foale M, Adkins SW (2005) Australian involvement in coconut research and development. pp 36-42 in Adkins SW, Foale M \& Samosir YMS (eds) Coconut revival-new possibilities for the 'tree of life'. Proceedings of the International Coconut Forum held in Cairns. 22-24 November 2005, Australia.

Staples GW, Bevacqua RF( 2006) Species profile for pacific island Agroforestry: Areca Catechu (Betel nut palm), websites: traditionaltree, Available from: www.traditionaltree.org. [11 September 2017].

Warner AT (1995) Marketing, valuation and pricing of NWFPS. Pp. 97-107 in Durst PB \& Bishop A (eds) Beyond timber: social, economic and cultural dimensions of non-wood forest products in Asia and the Pacific. 28 November - 2 December 1994, Bangkok.

Wiersum KF( 2006) Diversity and change in home garden cultivation in Indonesia. Pp 13-24 in Kumar BM \& Nair PKR (eds) Tropical Home gardens: A Time-Tested Example of Sustainable Agroforestry. Springer, Dordrecht. 